\title{
Effects of Organizational Trauma on Staff Skills in a Private Hospital in Iran
}

\author{
Mohammad Ali Sarlak', Pirhossein Kolivand ${ }^{1,2^{*}}$ \\ ${ }^{1}$ Department of Organizational Behavior Management, School of Management, Payame Noor University, Tehran, Iran \\ ${ }^{2}$ Shefa Neuroscience Research Center, Khatam Alanbia Hospital, Tehran, Iran
}

\section{A BSTRACT}

Introduction: Organizational trauma theory is perhaps one of the newest theories in organizational behavior and management fields, which is aimed to investigate the psychological and physical side effects of organizational trauma for individual and group in an organization. The aim of this study was to investigate the effects of organizational trauma on the skills of employees working in Khatam Alanbia Hospital, Tehran, Iran. Materials and Methods: PLS and organizational trauma questionnaires were used. The effects of this trauma on different skills of hospital staffs were investigated. Results: Our data revealed a significant correlation between organizational trauma and staff skills in different dimensions. Conclusions: Organizational trauma can reduce employee skills in workplace. If this trauma lasts for a long period, it can affect organizational productivity.

\section{Key words:}

1. Hospitals

2. Efficiency

3. adverse effects

*Corresponding Author: Pirhossein Kolivand

E-mail: peirhossein@yahoo.com 


\title{
تأثيرات تروماى سازمانى بر مهارتهاى كاركنان در يك بيمارستان خصوصى در ايران
}

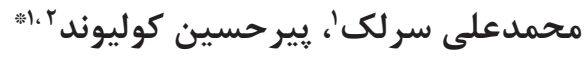 \\ اكروه مديريت رفتار سازمانى، دانشكده مديريت، دانشًاه بيام نور، تهران، ايران \\ rمركز تحقيقات علوم اعصاب شفا، بيمارستان خاتمالانبياء، تهران، ايران
}

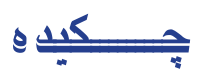

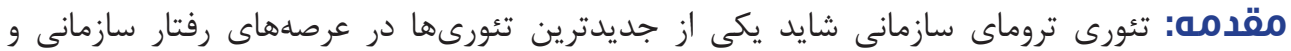

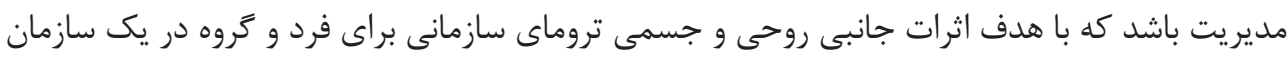

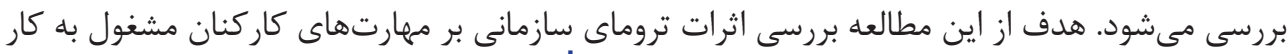

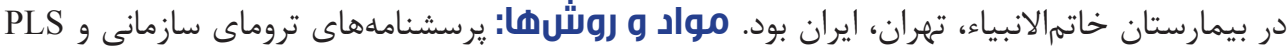

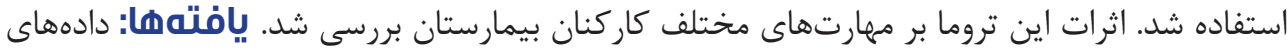

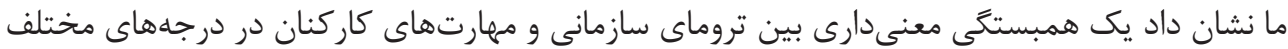

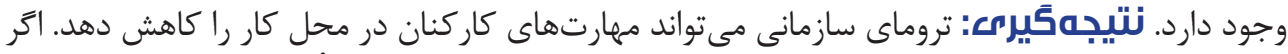

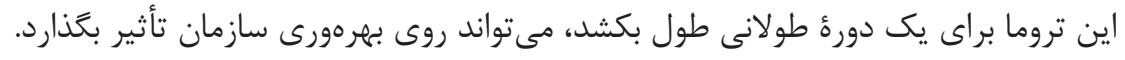


صـورت كســترده اتفــاق افتـاده باشــند در نهايست منجـــر بــهـ

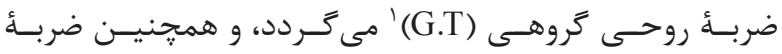

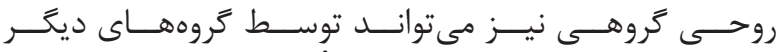

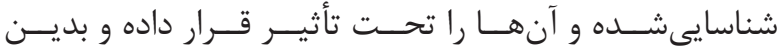

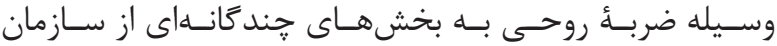

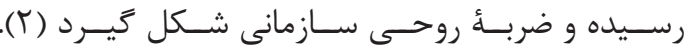
ضربه روحى در سطح سازمانى

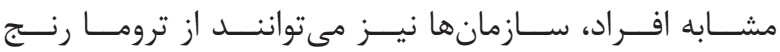

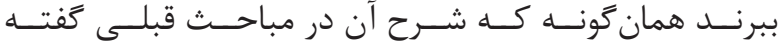

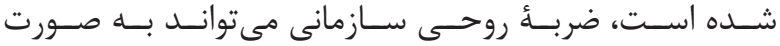

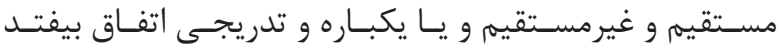

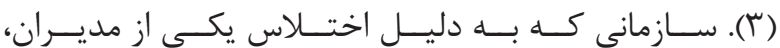

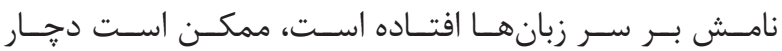

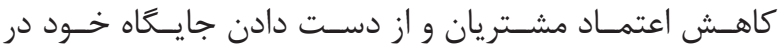

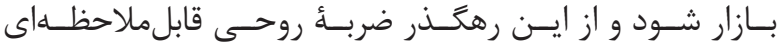

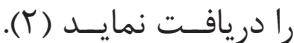
ضربه روحى در سطح جامعه

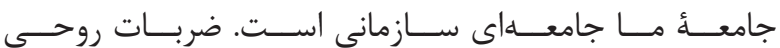

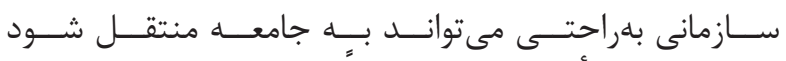

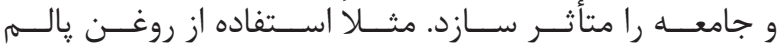

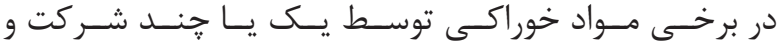

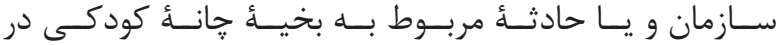

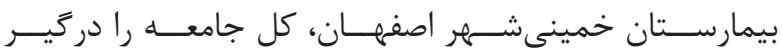

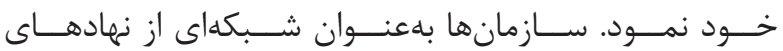

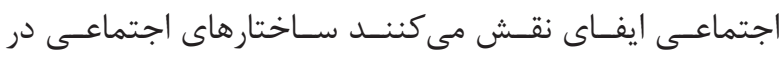

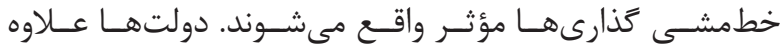

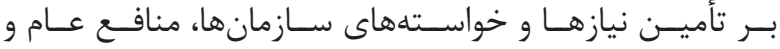

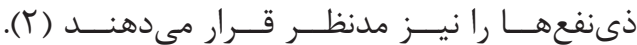

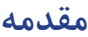

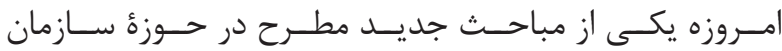

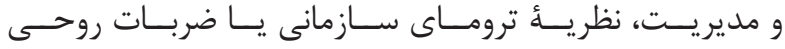

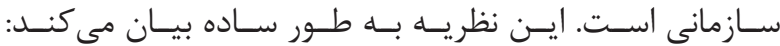

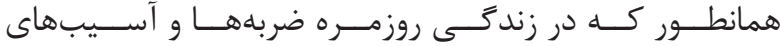

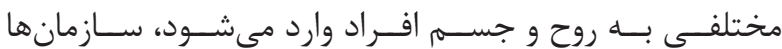

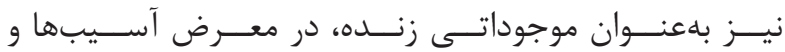

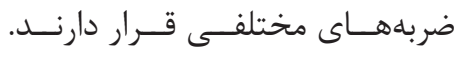

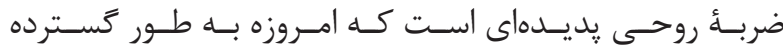

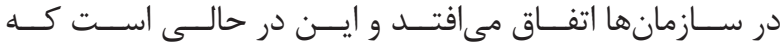

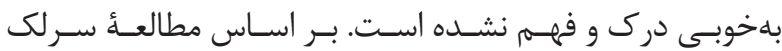

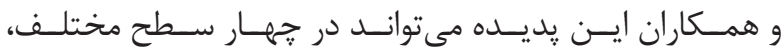

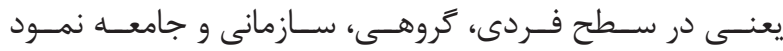

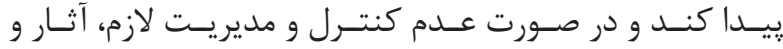

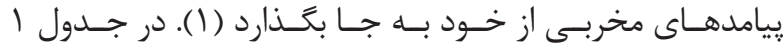

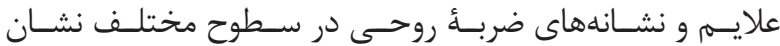

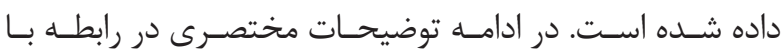

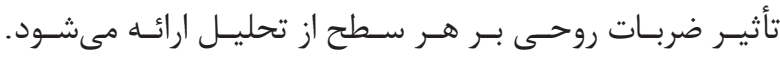
ضربأُ روحى در سطح فردى

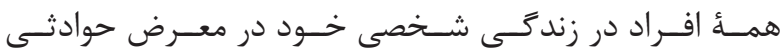

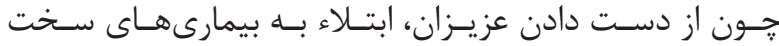

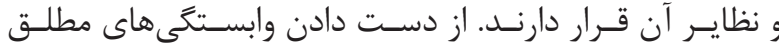

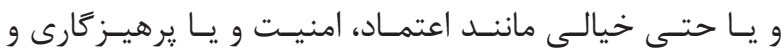

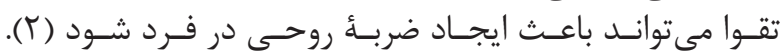
ضربأُ روحى در سطح َروهى

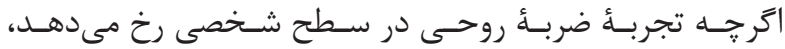

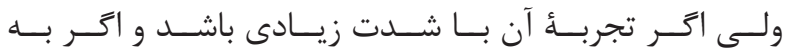

جدول (- علايم و نشانههاى ضربأ روحى در سطوح مختلف (1)

\begin{tabular}{|c|c|c|c|}
\hline سطح جامعه & سطح سازمانى & سطح كروهى & سطح فردى \\
\hline 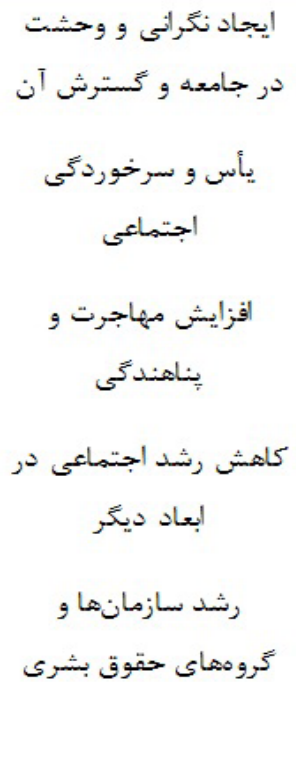 & 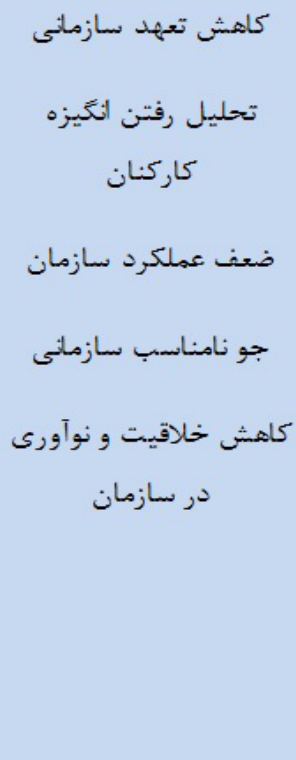 & 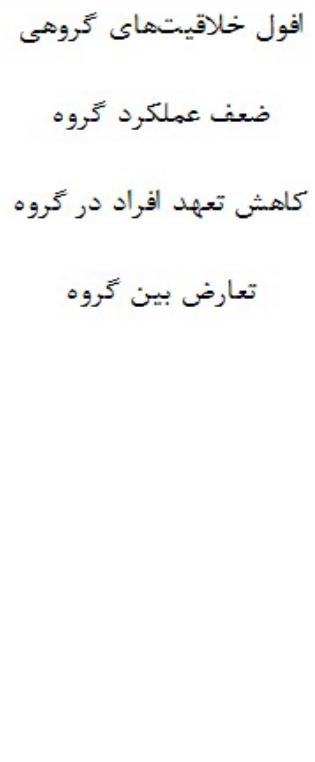 & 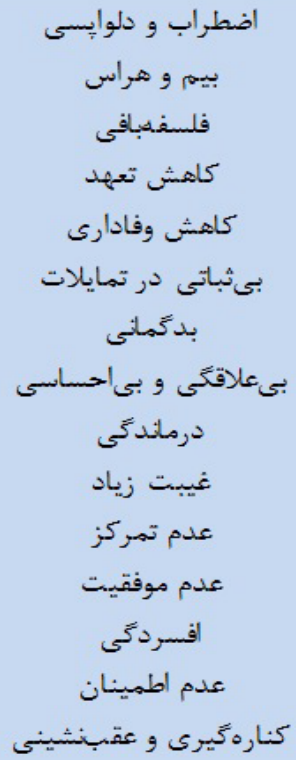 \\
\hline
\end{tabular}




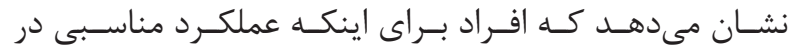

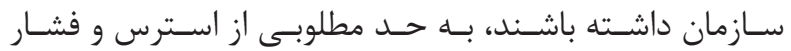

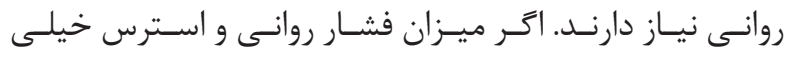

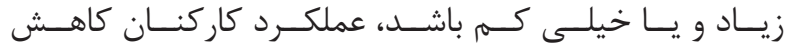

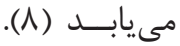

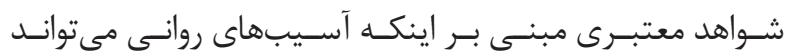

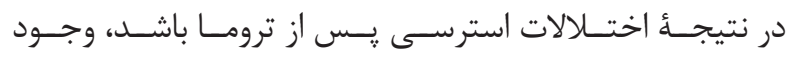

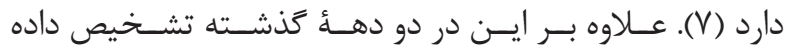

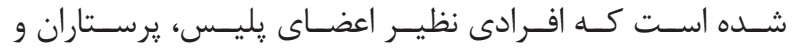

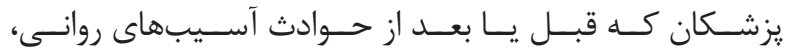

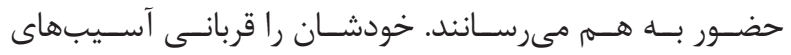

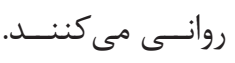

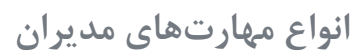

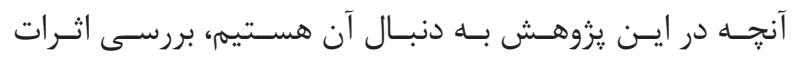

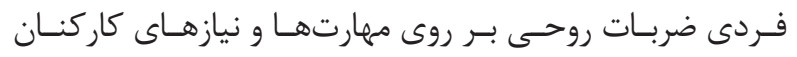

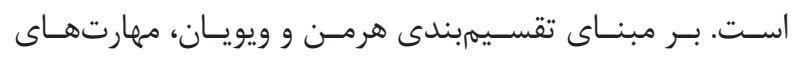

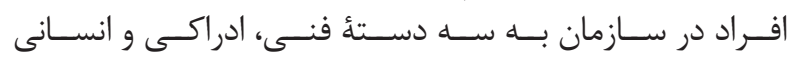

تقسـيم مىشــوند (9).

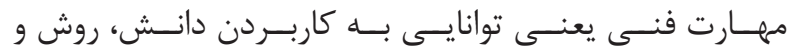

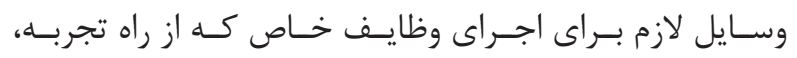

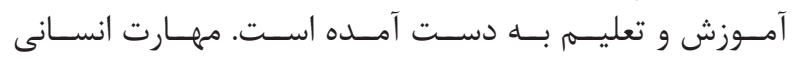

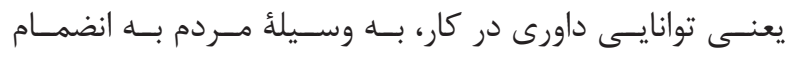

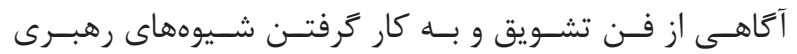

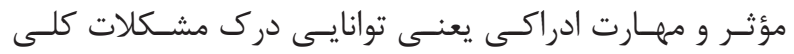

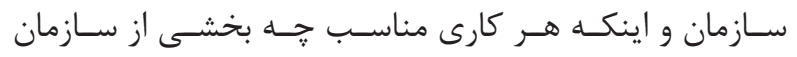

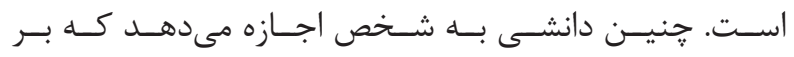

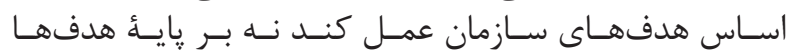

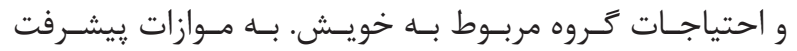

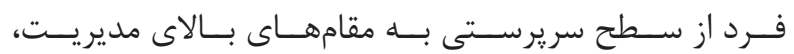

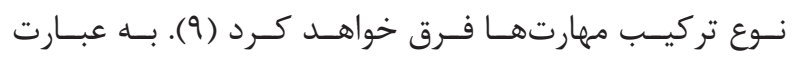

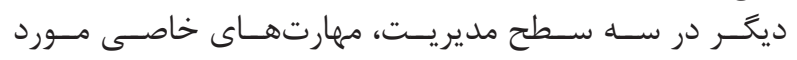

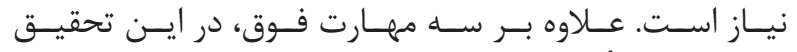

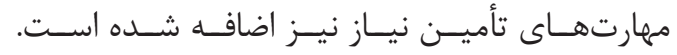

$$
\text { بيامدهاى ضربهُ روحى سازمانى }
$$

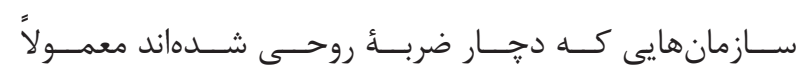

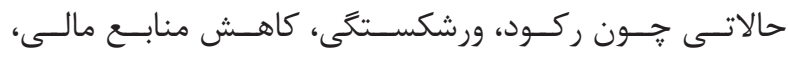

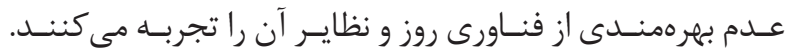

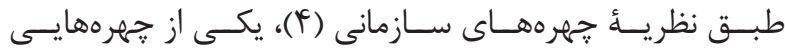

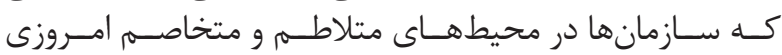

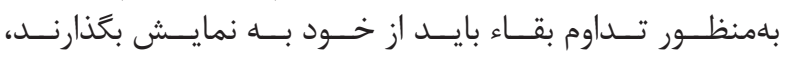

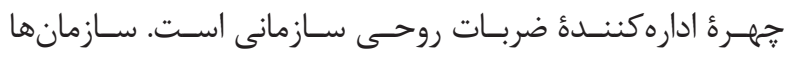

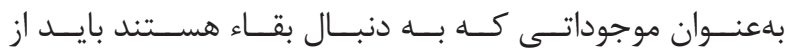

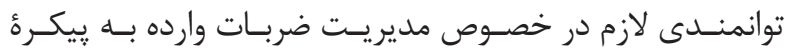

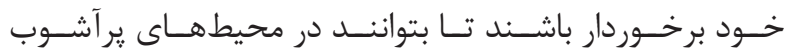

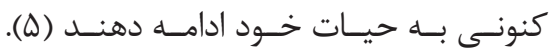
تعريف ضربهُ روحى تصى

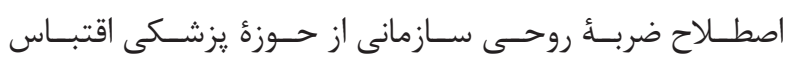

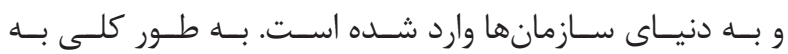

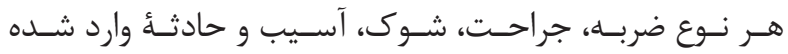

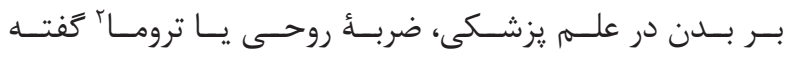

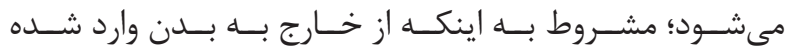

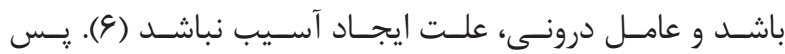

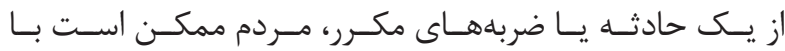

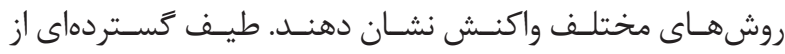

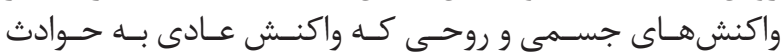

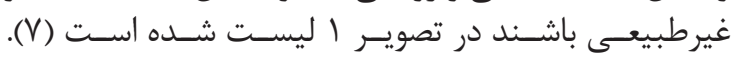

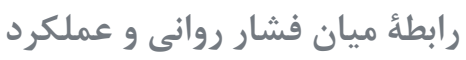

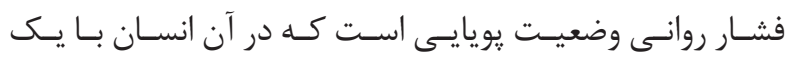

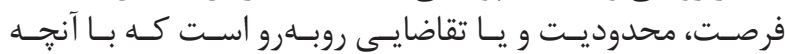

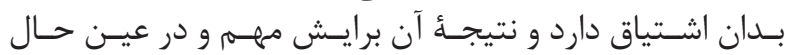

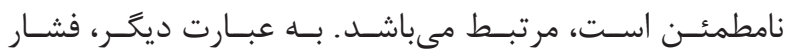

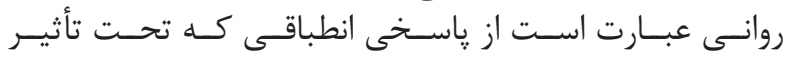

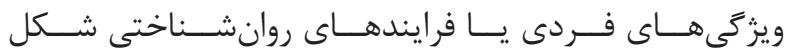

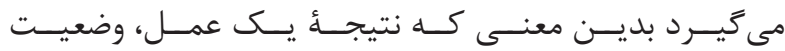

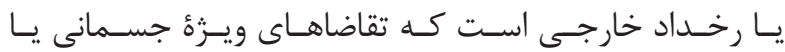

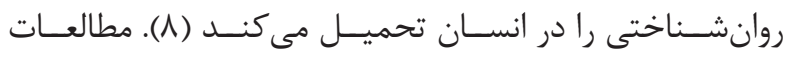

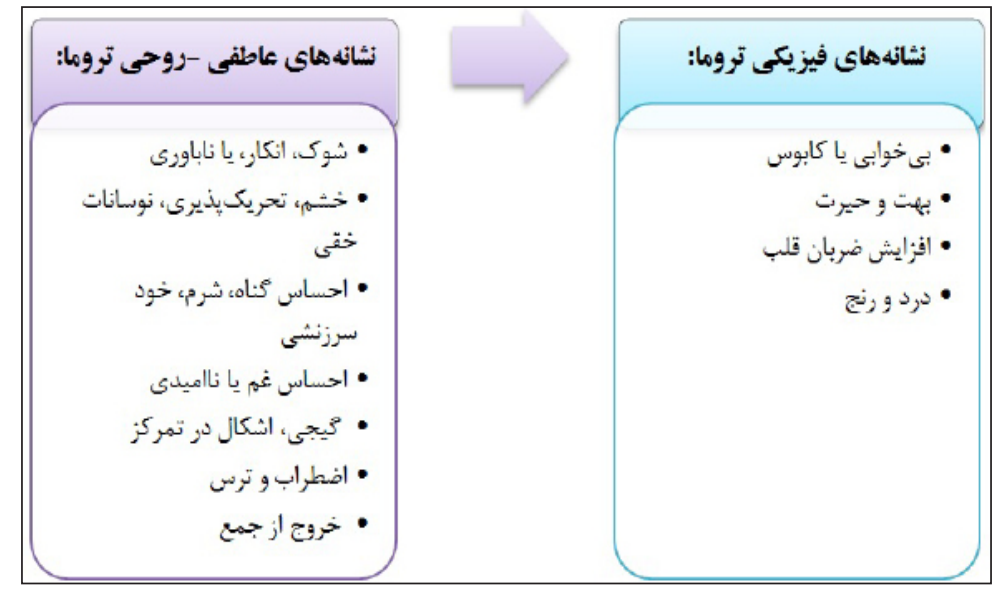

تصوير ا- نشانهاى عاطفى -روحى و فيزيكى تروما (ه). 


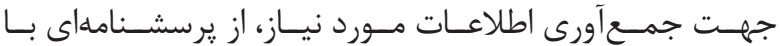

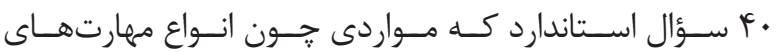

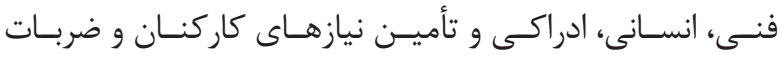

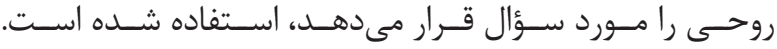

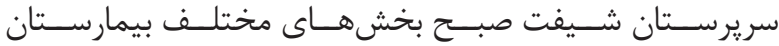

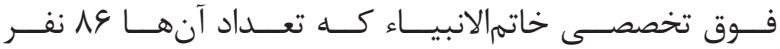

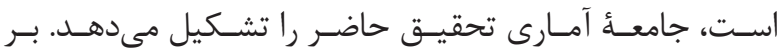

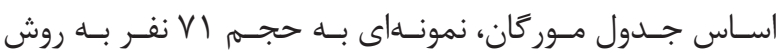

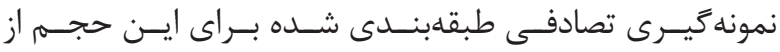

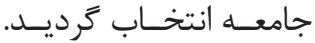

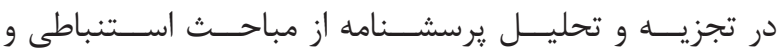

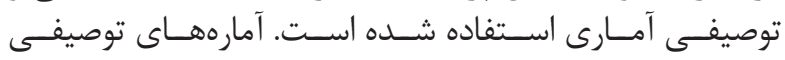

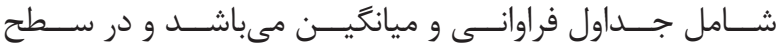

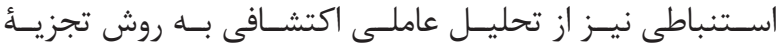

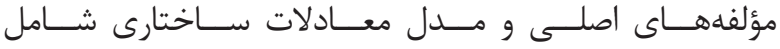

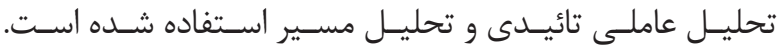

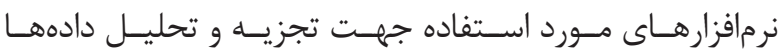

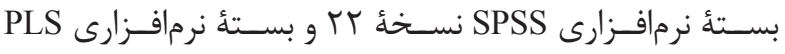

$$
\text { نســخه ب مى باشـــند. }
$$

\section{ج - بررسى روايى ابزار}

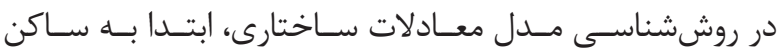

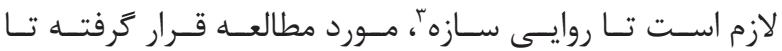

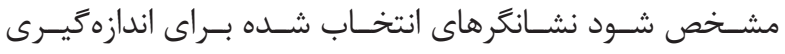

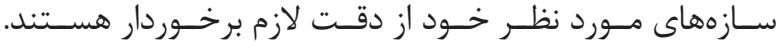

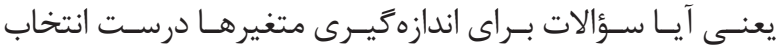

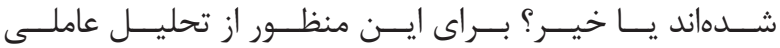

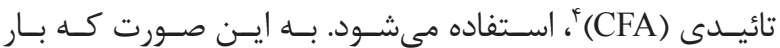

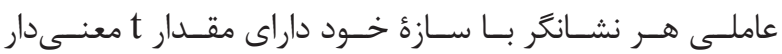

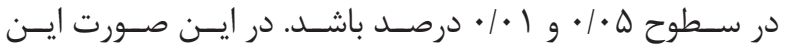

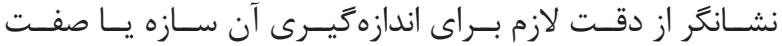

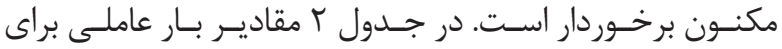

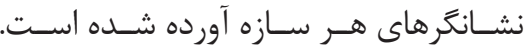

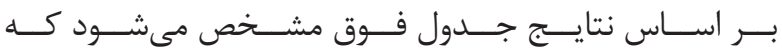

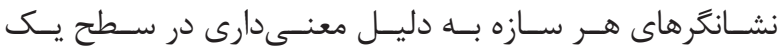

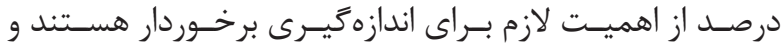

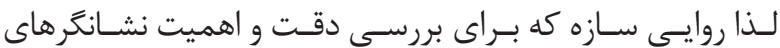

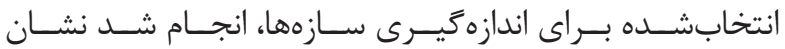

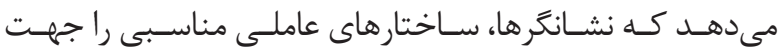

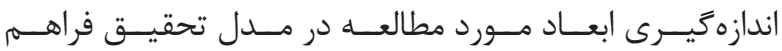

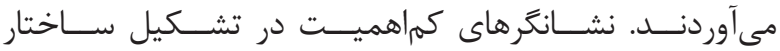

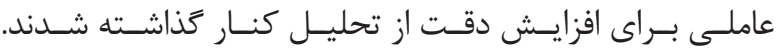

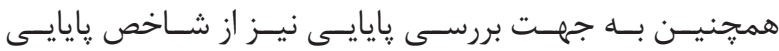

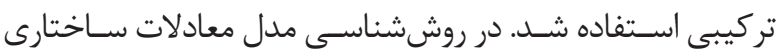

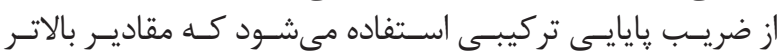

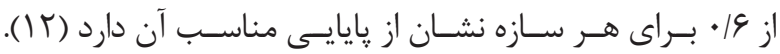

${ }^{3}$ Construct validity

${ }^{4}$ Confirmatory factor analysis
تأثير ضربات روحى بر مهارتهاى كاركنان

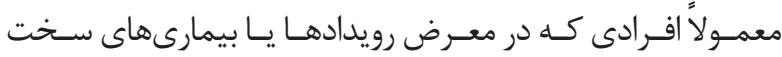

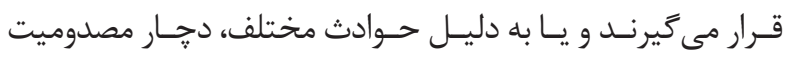

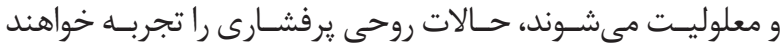

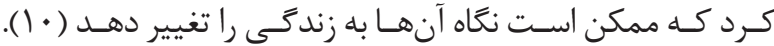

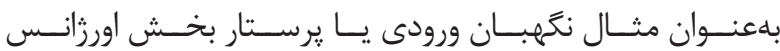

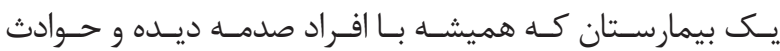

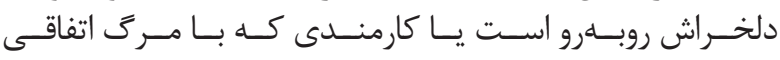

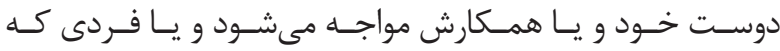

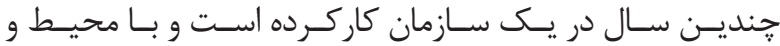

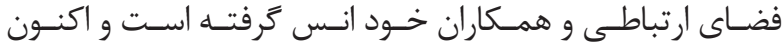

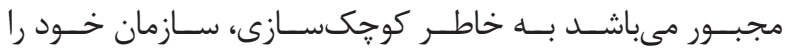

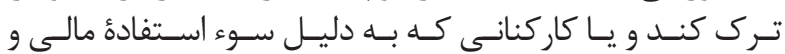

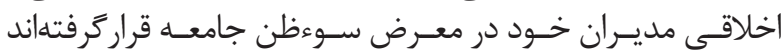

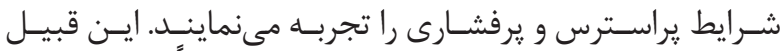

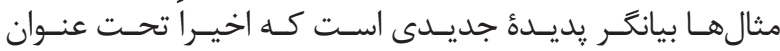

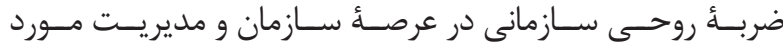

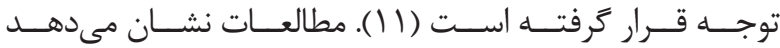

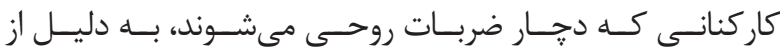

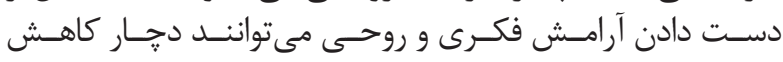

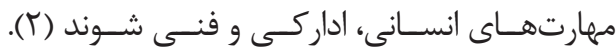

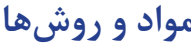

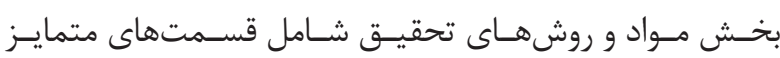

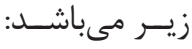

الف - هدف و فرضيات تحقيق

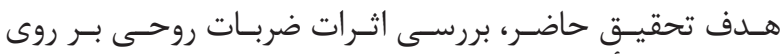

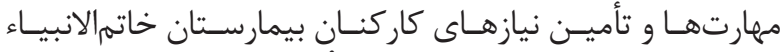

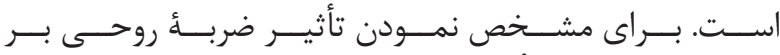

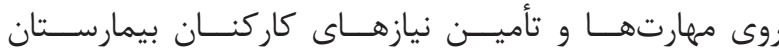

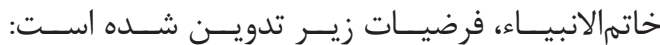

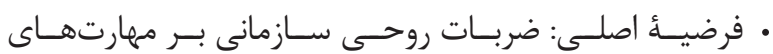

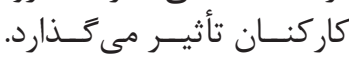

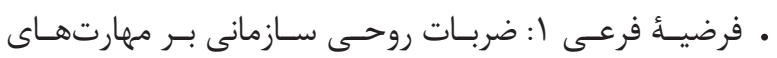
فنسى كاركنـان تأثيــر مى فـــارد.

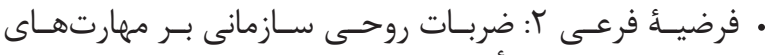
انسـانى كاركنـان تأثيـر مى فـــــارد.

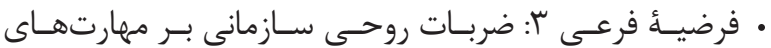

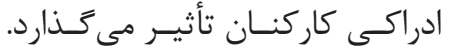

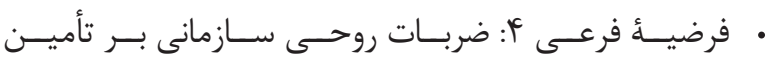

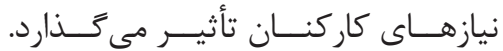

\section{ب- روش تحقيق و ابزار تحقيق}

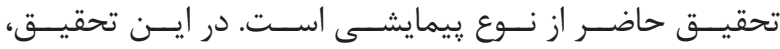


جدول Y- مقادير بار عاملى براى نشانكَرهاى هر سازه در قالب مدل اندازءكيرى.

\begin{tabular}{|c|c|c|c|c|}
\hline $\mathbf{t}$ & بار عاملى & عامت در مدل & تويه & سازه \\
\hline$r / r \Lambda \cdot$ & $\cdot|\Lambda 9|$ & b) & بهردمندى برسنل از دانش فنى و تخصص لازم براى انجام كارها & \multirow{10}{*}{ فهارتهاى } \\
\hline--- & -- & br & انجام سريع كارها توسط برسنل & \\
\hline--- & --- & br & انجام دقيق كارها توسط يرسنل & \\
\hline-- & --- & bf & انجام كارها به صورت كامل و درست & \\
\hline--- & --- & $\mathrm{b} \Delta$ & انجام كارها به صورت با كيفيت توسط يرسنل & \\
\hline $1 / \Delta \wedge \Lambda$ & . IAYF & be & انجام كارها به صورت امن توسط پرسنل & \\
\hline $1 / 949$ & $\cdot / 99$. & $\mathrm{bV}$ & انجام كارها با هزينـة قابلقبول توسط پرسنل & \\
\hline-- & -- & $\mathrm{b} \wedge$ & ارائه ايدههاى خلاقانه توسط پِرسنل & \\
\hline-- & -- & bq & تبديل ايدهها به محصول و خدمت توسط ٍرسنل & \\
\hline--- & --- & $\mathrm{bl}_{1}$. & حل مسائل كارى توسط پرسنل & \\
\hline-- & --- & b) & ارتباط مناسب كاركنان با همديكّر & \multirow{9}{*}{ مهارتهاى انسانى } \\
\hline-- & --- & bIr & ارتباط مناسب كاركنان با مافوق & \\
\hline--- & --- & bIr & ارتباط مناسب كاركنان با بيماران & \\
\hline--- & -- & bif & ارتباط مناسب كاركنان با همراهان بيمار & \\
\hline $1 / 9 \Delta 9$ &.$/ 994$ & b) 10 & رفتارهاى فراتر از وظيفه در كاركنان & \\
\hline I/VIr & $\cdot / V \vee q$ & ble & رفع تضاد و سوء تفاهمات كارى توسط كاركنان & \\
\hline $1 / 9 \cdot 1$ & $\cdot / \mathrm{VAV}$ & bIV & مسئوليت קذيرى كاركنان & \\
\hline r/IVG &.$/ 19 \Delta$ & $b \backslash \wedge$ & انتقاد يذيرى كاركنان & \\
\hline--- & -- & $b 19$ & رعايت اخلاقيات توسط كاركنان & \\
\hline r/r & . & br. & درك مأموريت سازمان توسط شما & \multirow{6}{*}{ مهارتهاى ادراكى } \\
\hline$r / r q$. & ./941 & bri & درك جششم انداز سازمان توسط شما & \\
\hline r/rV & $\cdot / 9 M T$ & brt & درك ارزشهاى سازمانى توسط شما & \\
\hline$r / .99$ & $\cdot / 9 \cdots$ & bru & درك وظايف و مأموريت ساير بخشهاى سازمان توسط شما & \\
\hline$r / \ldots$ & $\cdot / 9 \cdots$ & brf & درك اثر تغييرات سازمانى بر نتايج مورد انتظار واحد كارى شما & \\
\hline r/AFV & - ATEG & bro & درك اثر تغييرات سازمانى بر نتايج مورد انتظار ساير واحدها & \\
\hline r/VEq &.$/ G V Y$ & bre & تفويض اختيارات لازم به يرسنل در بيمارستان & \multirow{10}{*}{ ت ت تأمين نيازها } \\
\hline$r / 9 \Lambda$. & - /VDr & brv & رفع نيازهاى اساسى كاركنان (حقوق و مزايا، مسكن، خودرو، يوشاك) & \\
\hline r/Vfq & 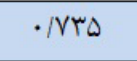 & bra & رفع نيازهاى اجتماعى و ارتباطى كاركنان & \\
\hline r/rVq & -/VAG & bra & احترام به عزت نفس و شخصيت كاركنان & \\
\hline $\mathrm{r} / \mathrm{q} \cdot 1$ & - /AV. & br. & رفع نيازهاى خود شكوفايى كاركنان (نياز به نوآورى، خلاقيت و...) & \\
\hline$r / \uparrow \wedge \Lambda$ & •/VQน & bri & رفع نيازهاى معرفتى (نياز به دانش، اطلاعات، اخلاق، معنويت) & \\
\hline T/VRG & $\cdot / \mathrm{ANV}$ & brt & توجه به نياز كاركنان به محل كار زيبا و آراسته & \\
\hline$r / V r$. & $\cdot / \vee 99$ & מש & امنيت شغلى كاركنان & \\
\hline$f / \cdot \Delta \cdot$ & ./^१४ & brf & امنيت كاركنان در اظهار نظر آزادانه & \\
\hline$f / \cdot r \Delta$ & $\cdot / A V R$ & bru & امنيت كاركنان در انتقاد سازنده & \\
\hline r/ITr & $\cdot / V \cdot \Lambda$ & bre & از دست دادن يزشكان حاذق & 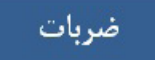 \\
\hline$f / T f \Delta$ & - /Afq & brv & از دست دادن يرستاران ماهر & روحى \\
\hline$V / \backslash \Delta r$ & $\cdot / 91 f$ & bru & از دست دادن سريرستاران با تجربه & سازمانى \\
\hline$\Lambda / f \cdot 1$ & - /NGK & bra & افت كيفيت به دليل קايين بودن سطح مهارت يرستاران جديدالورود & 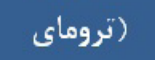 \\
\hline 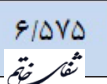 & $\cdot / 9 \wedge 9$ & bf. & محدود شدن بيمارستان به بيماران تضمين شدة بنياد شهيد & سازمانى \\
\hline
\end{tabular}




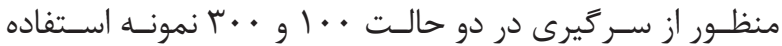

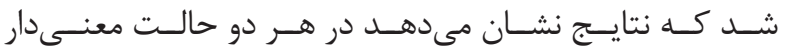

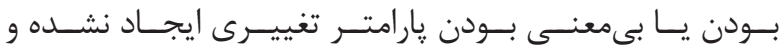

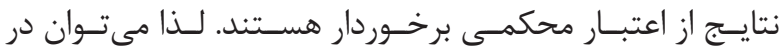

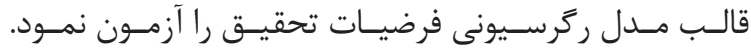
يافتهها

الف- ضربات روحى سازمانى بر مهارتهاى ادراكى كاركنان تأثير مى تذار

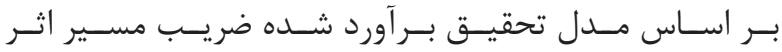

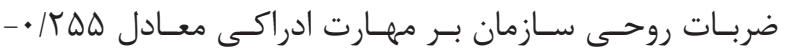

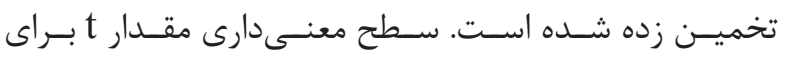

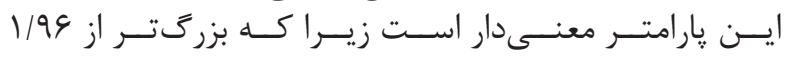

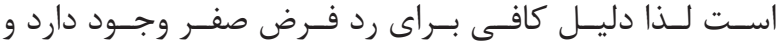

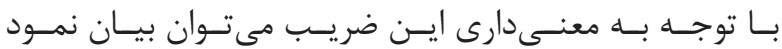

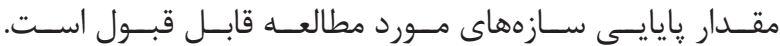

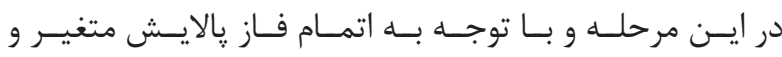

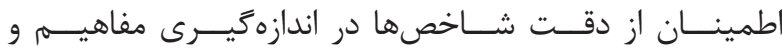

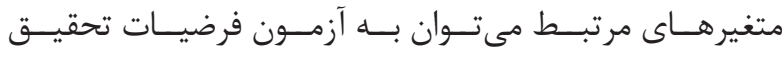

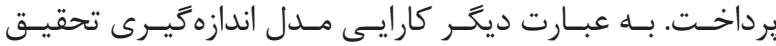

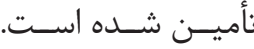

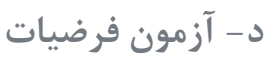

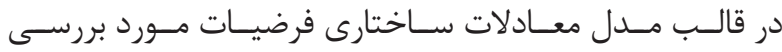

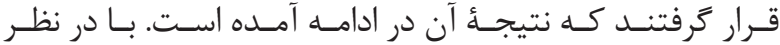

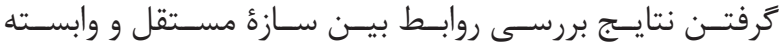

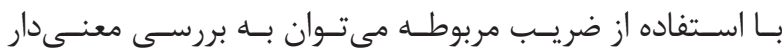

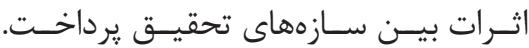

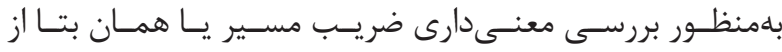

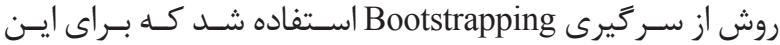

جدول ب- ضرايب بررسى پايايى سازهاى تحقيق.

\begin{tabular}{|c|c|c|}
\hline آلفى كرونباخ & هايايیى تركيبى & سـزٔ مورد مطالعه \\
\hline - IASC & $\cdot / q \cdot r$ & ضربات روحى سدزمان \\
\hline$\cdot / 9 \Delta \varphi$ & $\cdot / 994$ & مهيارت ادراكى \\
\hline •/AIT & $\cdot / A V$. & مهيارت انسسنتى \\
\hline -/QFY & $\cdot / 9 \Delta$. & ههارت تأمين نيازهاى كاركنـان \\
\hline $0^{*} \cdot 1091$ & $\cdot$ /VVY & مهارت فنى \\
\hline
\end{tabular}

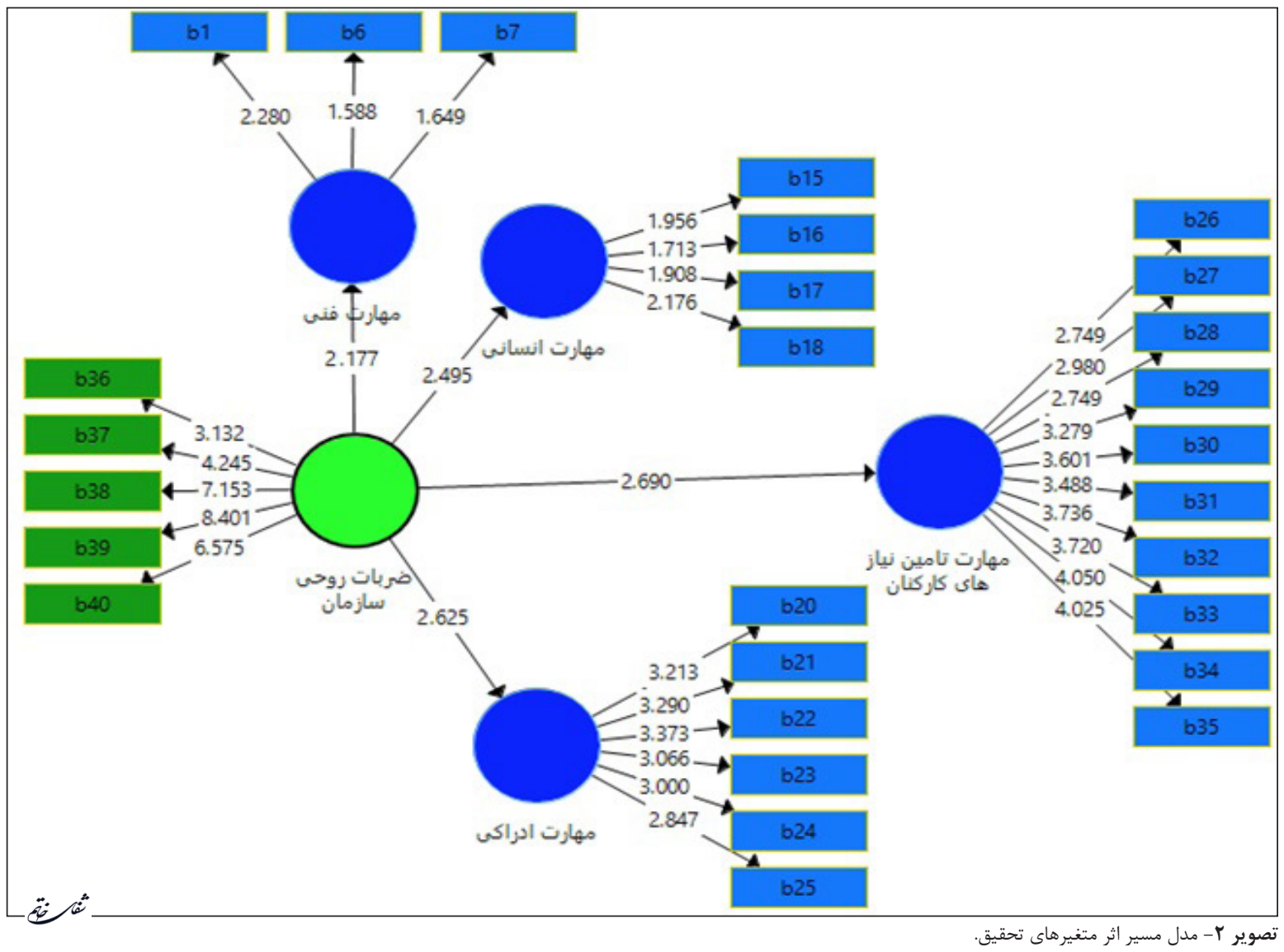




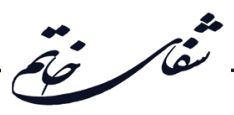

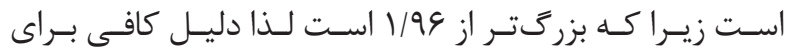

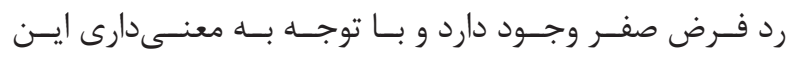

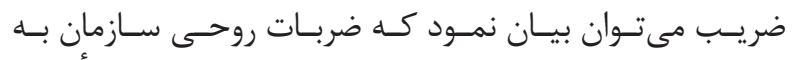

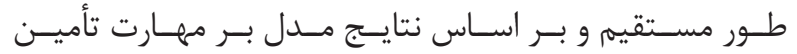

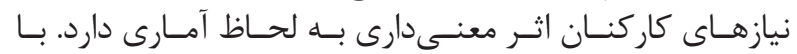

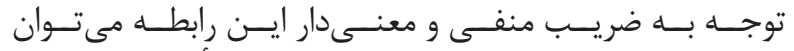

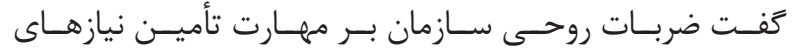

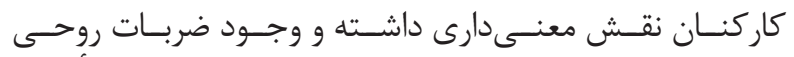

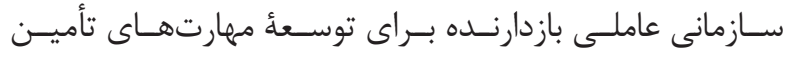

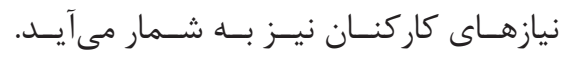

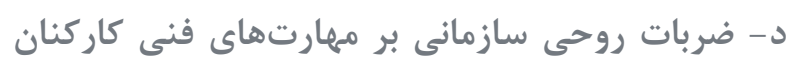
تأثير مى حذارد

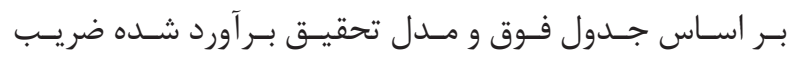

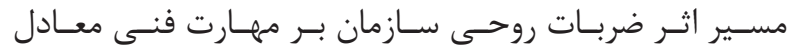

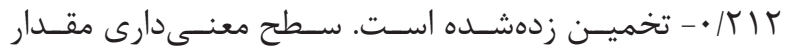

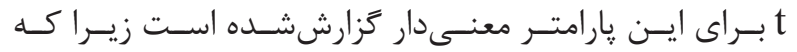

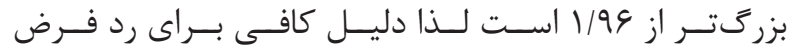

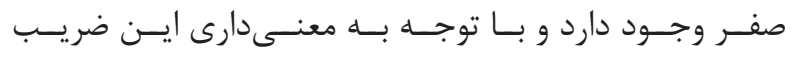

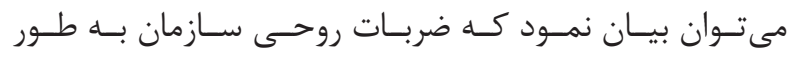

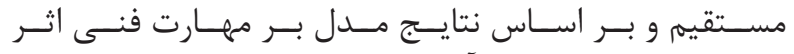

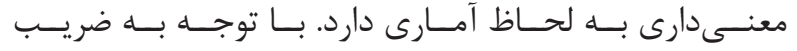

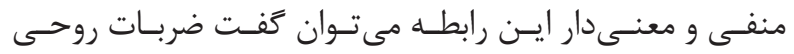

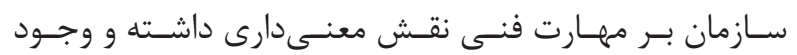

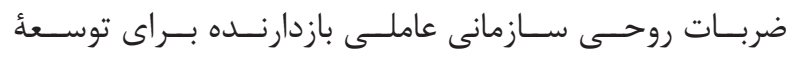

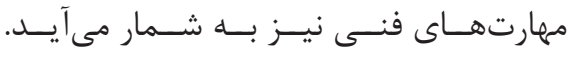

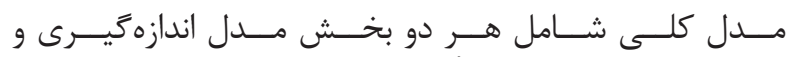

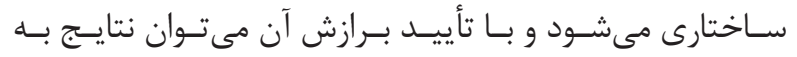

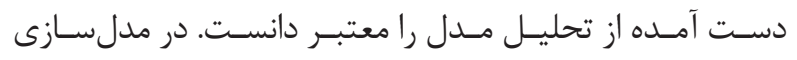

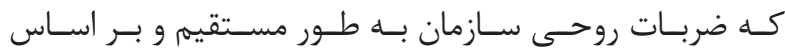

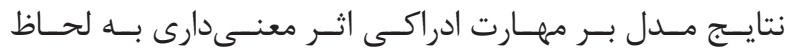

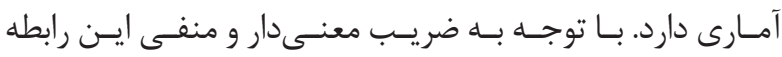

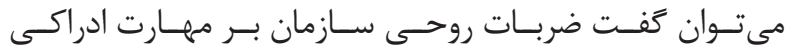

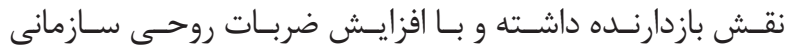

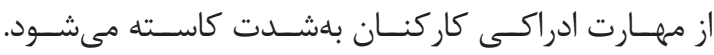
ب - ضربات روحى سازمانى بر مهارت هاى انسانى كار كنان

$$
\text { تأثير مي گذارد }
$$

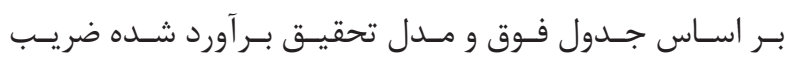

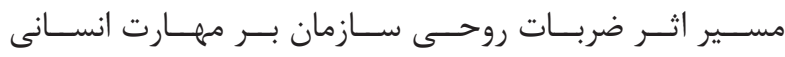

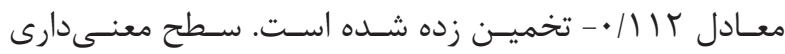

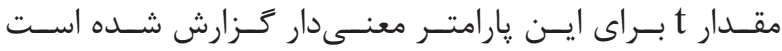

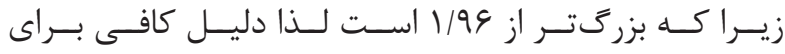

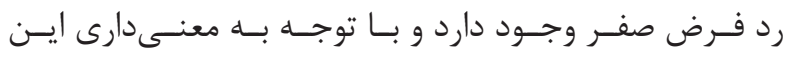

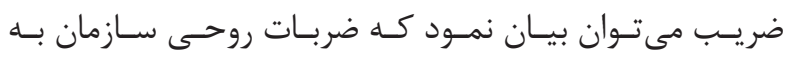

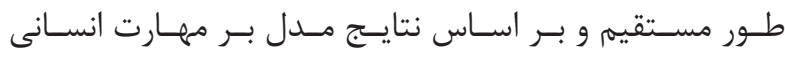

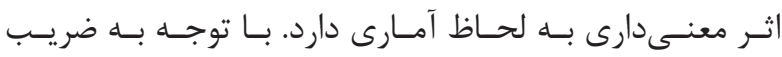

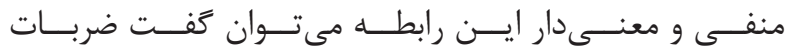

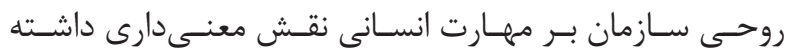

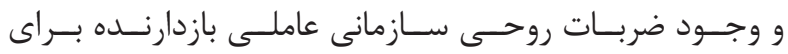

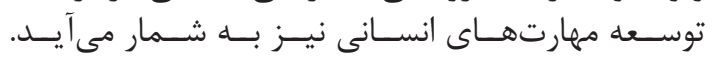
ج- ضربات روحى سازمانى بر تأمين نيازهاى كاركنان تأثير مى حذارد

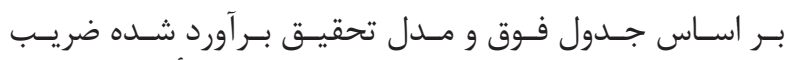

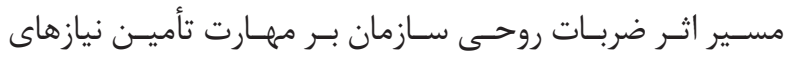

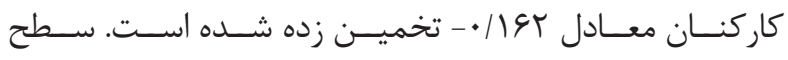

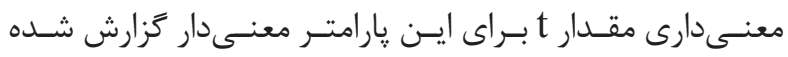

جدول \&- اثر خطى اثرات متغيرهاى تحقيق براى آزمون فرضيات كلى تحقيق.

\begin{tabular}{|c|c|c|c|c|c|}
\hline $\mathrm{R}^{2}$ & $\mathrm{~F}^{2}$ & $\mathrm{~T}$ & نتيجه & بتا & اثر خطى مورد مطالعه \\
\hline .1 .90 & $\cdot / \cdot \Delta t$ & T/ATS & 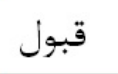 & $-\cdot / r \Delta \Delta$ & ضربات روحى سازمان ـ مهيارت ادراكى \\
\hline.$/ \cdot 11$ & $\cdot / \cdot r$ & $r / 4 q \Delta$ & 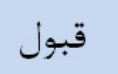 & $-\cdot / 114$ & ضربات روحى سازمان ـ مهارت انسانى \\
\hline.$/ \cdot$ TS &.$/ .14$ & $r / 99$. & 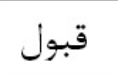 & $-\cdot / 19 T$ & ضربات روحى سازمان ـ تأمين نيازهاى كاركنان \\
\hline $\begin{array}{ll}-1 \cdot 40 \\
0 \\
0\end{array}$ & 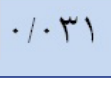 & T/IVV & 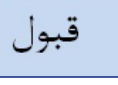 &.$- / 4 \pi$ & ضربات روحى سازمان ـ مهارت فنى \\
\hline
\end{tabular}

جدول ه- شاخصهاى برازش مدل مسيرى تحقيق به روش PLS.

\begin{tabular}{|c|c|c|c|}
\hline حدود مطلوب & سطح معنى دارى & مقدار محاسبه شده & 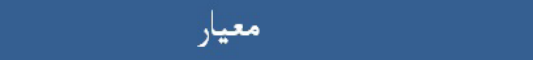 \\
\hline$<\cdot / \cdot \Delta$ & $\cdot 1 \cdot \cdot 1$ & $\cdot / \mid \Lambda F$ & متوسط شاخص مسير APC \\
\hline$\leq \omega$ & --- & $r / r \Delta \Lambda$ & ميانكين بلوك عامل تورش واريانس AVIF \\
\hline 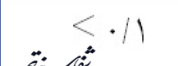 & --- & $\cdot / \cdot \Lambda \mathrm{r}$ & شاخص SRMR \\
\hline
\end{tabular}




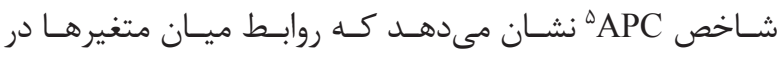

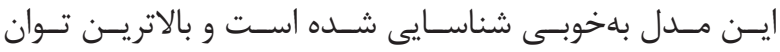

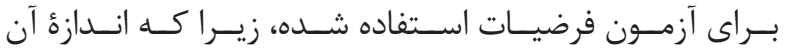

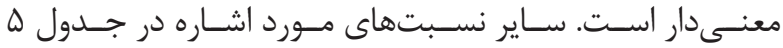

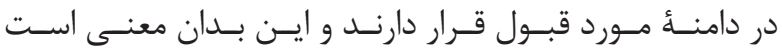

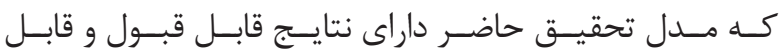

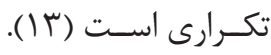
در نهايـت فرضيــ كلـى تحقيـق بيـان مسى دارد كه بيـن ضربات

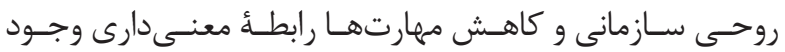

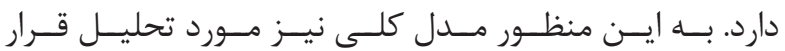

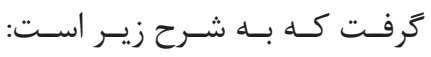

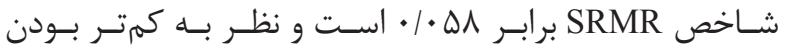

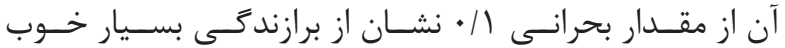

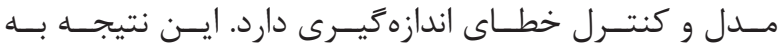

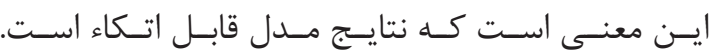

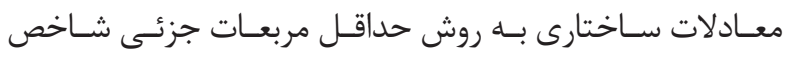

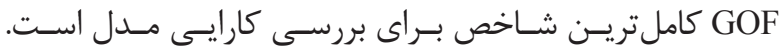

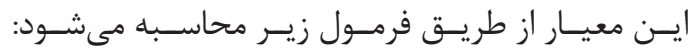

$$
G O F=\sqrt{\overline{\text { communalutles }} \times \overline{R^{2}}}
$$

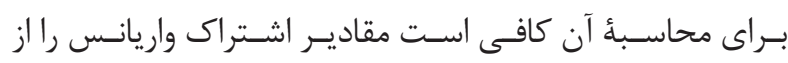

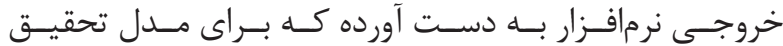

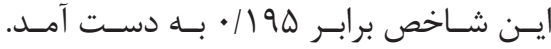

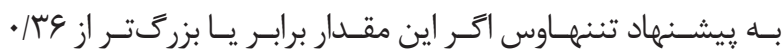

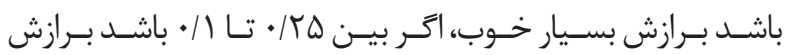

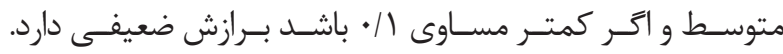

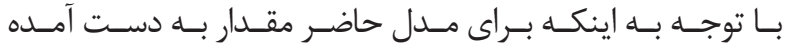

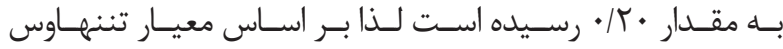

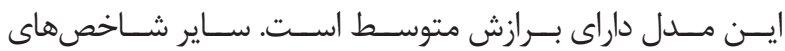

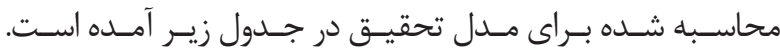

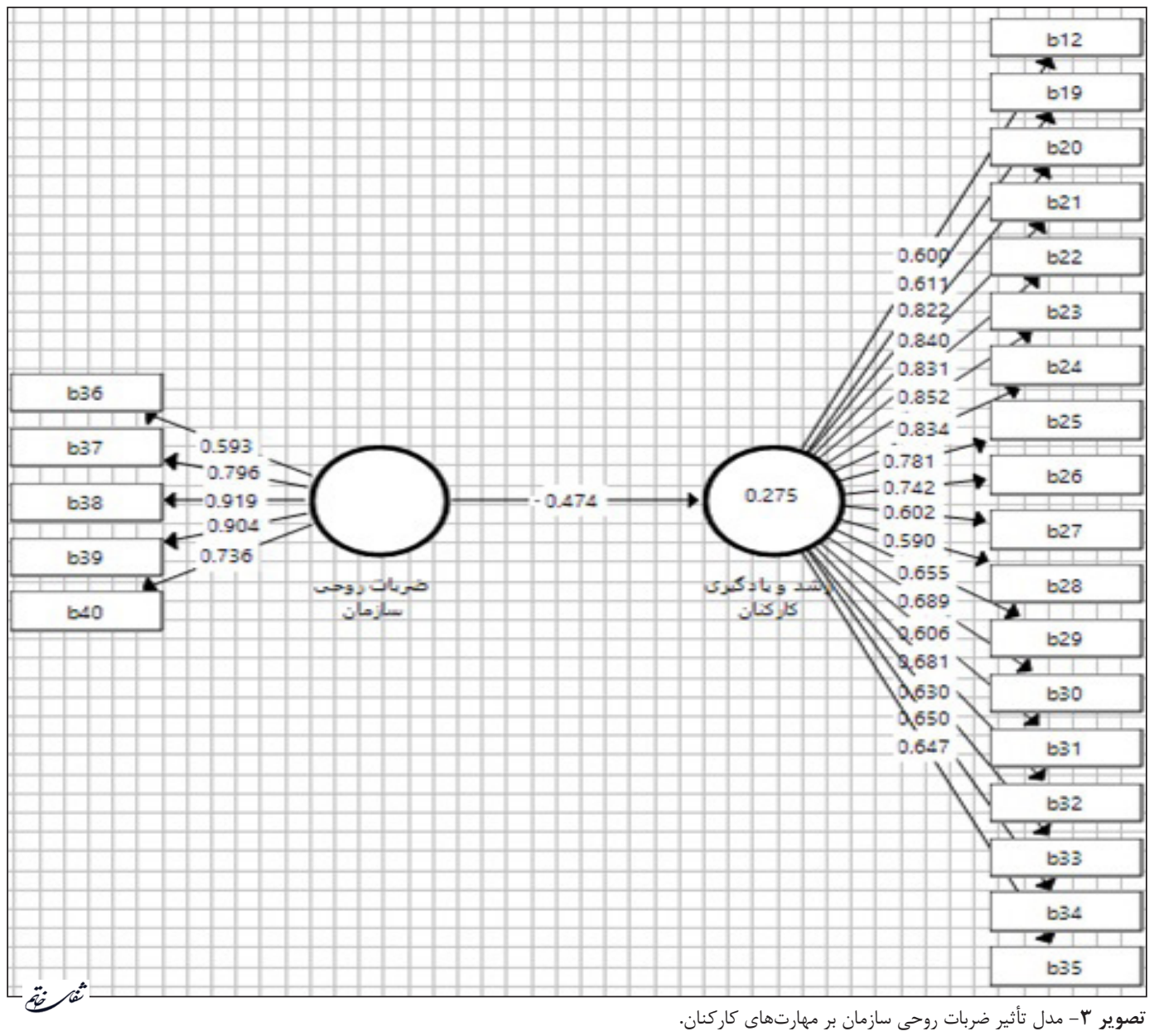

جدول צ- اثر خطى اثرات متغيرهاى تحقيق براى آزمون فرضيه كلى.

\begin{tabular}{|c|c|c|c|c|}
\hline $\mathrm{R}^{2}$ & $\mathrm{t}$ & نتيجه & بتا & اثر خطى مورد مطالعه \\
\hline $\begin{array}{ll}-\pi V D \\
-40\end{array}$ & $r / \Lambda F d$ & قبول & 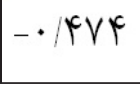 & ضربات روحى سازمان ـ مهارتهاى كاركنان \\
\hline
\end{tabular}

${ }^{5}$ Average path coefficient 


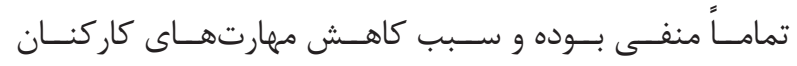

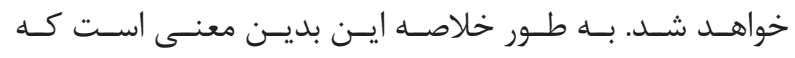

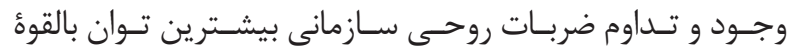

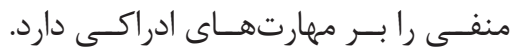

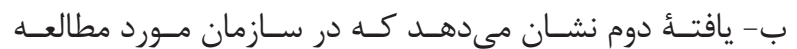

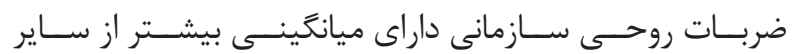

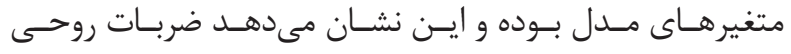

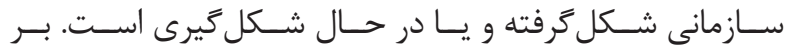

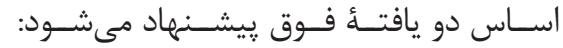

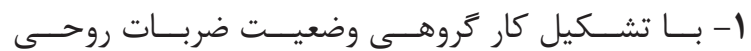

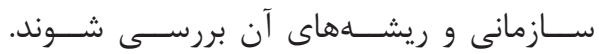

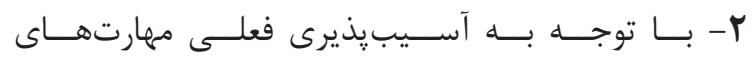

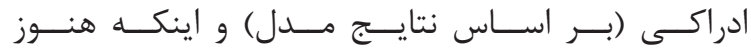

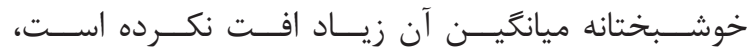

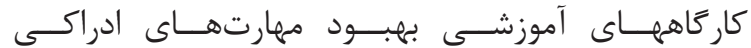

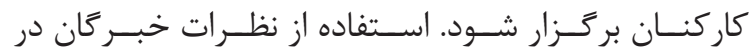

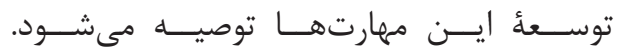

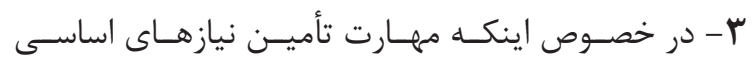

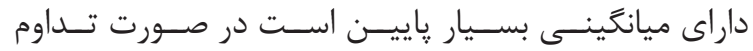

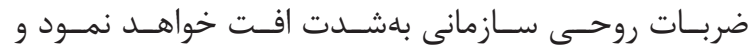

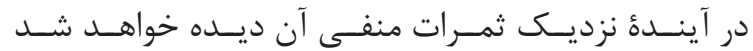

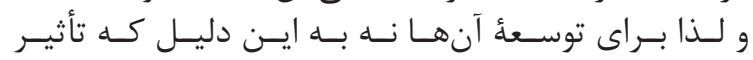

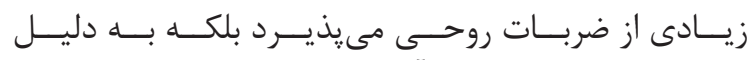

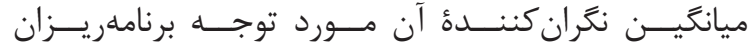

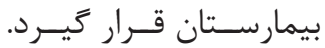
F- فضـاى بهتـــ بـراى انتقـاد سـازندة كار كنان فراهـم آيد.

1. Sarlak MA, Shirazi S, Kolivand P. Trauma management organization. Tehran. Mirmah Publisher. 2016.

2. Ahmadi F, Shirazi S. Design and describe the trauma department of dimension organizations in the governmental section. Journal of Management of Government Agencies. 2014; 3(10): 91-106.

3. Shirazi S. Define and design a governance model organizational trauma. PhD Thesis. Tehran. Payame Noor University. 2014.

4. Rezaiyan A. Principles of organization and management. Tehran. Samt Publisher. 2004.

5. Allagheh Band A. Public management. $3^{\text {rd }}$ ed. Tehran. Ravan Publisher. 1983.

6. Sarlak MA. The newfound in the twenty-first century. 1st ed. Tehran. Marjae Danesh Publisher. 2012; p. 224.

7. Trauma. Wikipedia. https://fa.wikipedia.org/ wiki/\%D8\%AA\%D8\%B1\%D9\%88\%D9\%85\% D8\%A7.

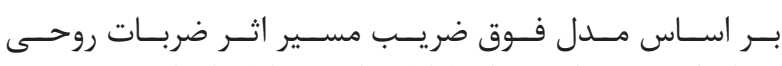

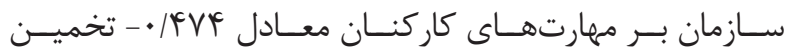

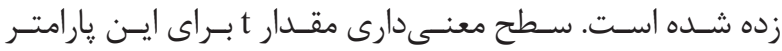

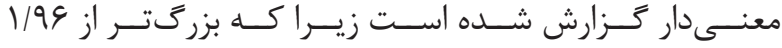

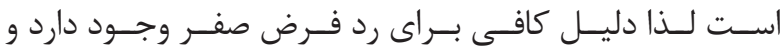

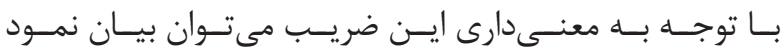

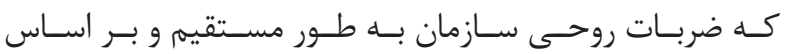

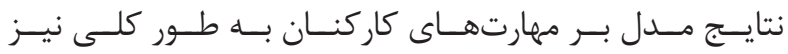

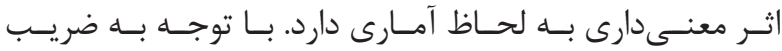

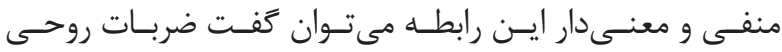

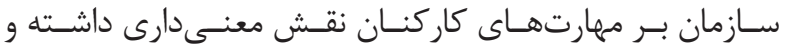

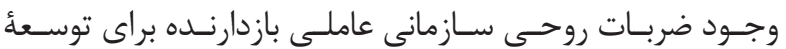

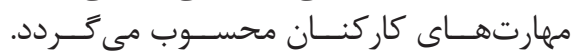

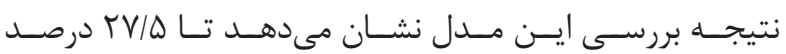

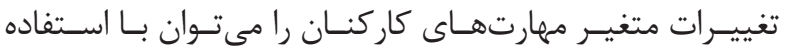

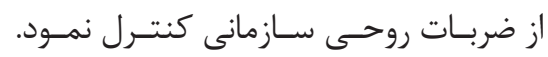
بحث و نتيجه كيرى

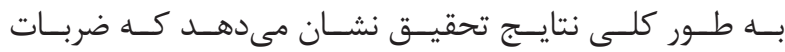

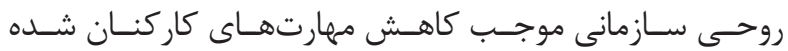

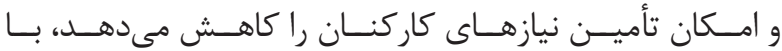

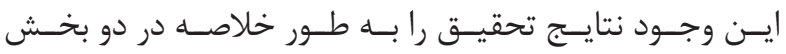

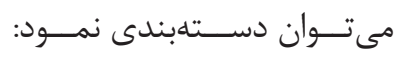

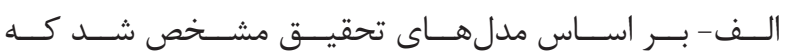

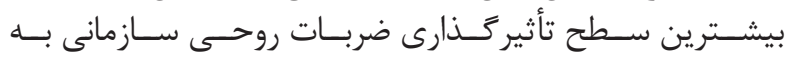

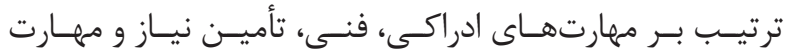

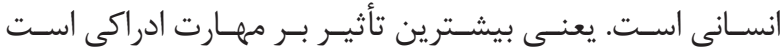

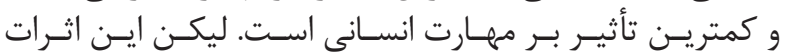

منابع

8. The organization's face. Wikipedia. https:// en.wikipedia.org/wiki/The_organization $\% 27 \mathrm{~s}$ _face.

9. Hormann S, Vivian P. Toward an understanding of traumatized organizations and how to intervene in them. Traumatology. 2005; 11(3): 159-9.

10. Vivian P, Hormann S. Persistent traumatization in nonprofit organizations. OD Practitioner. 2015; 47(1): 25-30.

11. Vivian P. Hormann S. Organizational trauma and healing. CreateSpace Independent Publishing Platform. 2013; p. 978.

12. Nunnally JC, Bernstein IH. Psychometric theory. $3^{\text {rd }}$ ed. New York: McGraw-Hill. 1994.

13. Nevitt J, Hancock GR. Performance of bootstrapping approaches to model test statistics and parameter standard error estimation in structural equation modeling. A Multidisciplinary Journal. 2001; 8(3): 353-77. 